\title{
Analysis of population vulnerability towards the spread of COVID-19 in Malang Raya from a spatial perspective
}

\author{
Purwanto*, Ike Sari Astuti, Ardyanto Tanjung \& Fatchur Rohman \\ Universitas Negeri Malang, Malang, Indonesia
}

\begin{abstract}
This study aimed to analyze the characteristics of the population's vulnerability to the spread of COVID-19 in Malang Raya from spatial perspectives. We use an elderly population of $60+$ to analyze the spatial characteristics of regional vulnerabilities and spatial analysis of the spread of COVID-19 in Malang Raya from March-June 2020. Also, we divide population vulnerability zones into two zones, by distinguishing vulnerabilities by gender. The main findings are as follows: (1) based on the analysis results, rural areas are more vulnerable to the spread of COVID-19. A strong immune system causes COVID-19 not to develop in rural areas. (2) The spatial distribution of COVID-19 in Malang Raya is still concentrated in urban areas with distribution patterns following accessibility paths. (3) Older women have a higher vulnerability level to COVID-19 than men, but women have a better awareness of spatial adaptation in using personal protective equipment.
\end{abstract}

\section{INTRODUCTION}

Coronavirus Disease 2019, more commonly known as COVID-19, is an outbreak of infectious diseases caused by viruses in animals and transmitted rapidly in humans (Contini et al. 2020). COVID-19 is emerging as a new disease and becoming a major health threat in every country, especially a country with a very large population. The emergence of COVID-19 originated in Wuhan, China, in December 2019 under Severe Acute Respiratory Syndrome Coronavirus 2 (SARS COV2) (Bhattacharya et al. 2020). According to a study, in addition to attacking the respiratory system in humans, researchers in Shanghai and New York reported that COVID-19 could also attack the immunity or human immune system and cause similar damage to patients with HIV (Otálora 2020).

The spread of COVID-19 throughout the world is very fast because it has moved the transmission system from human to human (Shereen et al. 2020). Lack of treatment and experience due to unknown patterns and ways the virus works made it so no vaccine has been found. One of the efforts to minimize the impact is to break the chain through various actions and policies. Lockdowns, social distancing, Large-Scale Social Restrictions (PSBB), Local Social Restrictions (PSBL), selfisolation and the use of personal protective equipment and provide legal restrictions for violators of health protocols are all forms of policies and measures to minimize the spread of COVID-19. However, the extent to which the policy is effective the results are not yet clear (Lau et al. 2020), as the current number of positive cases continues to increase.

According to some experts, lockdown policies can reduce the risk of infection and death from COVID-19. As in the UK, Lockdown was able to drop 25\% a week after the policy was enacted (Thornton 2020). However, there are several problems in the socio-economic sphere, including rapidly increasing discrimination and gender violence; formal and informal business sectors, the economy, and education are hampered; loss of livelihoods and rising unemployment are causing misery, especially the urban and rural poor (Shammi et al. 2020). Oversleeping occurs, resulting

\footnotetext{
*Corresponding author: purwanto.fis@um.ac.id
} 
in physical and mental health disorders such as mild depression (low mood) during lockdowns (Majumdar et al. 2020).

COVID-19 can be transmitted in various media, either through direct or indirect contact. Direct transmission is the case of direct contact with the sufferer. Transmission can occur through coughing, sneezing or splashing coming out of an infected person's mouth and nose. The particle can then also stick to objects that humans often touch. Therefore, the spread of the virus becomes very fast (WHO 2020).

Rising positive cases in various countries are causing public concern globally (Lau et al. 2020), including who (Word Health Organization) is the world health organization. Therefore, as an anticipatory action, it is necessary to perform vulnerability analysis to see a region's status, taking into account age as a vulnerability indicator. Age is the basis in determining the ratio of vulnerability to COVID-19 because of the large number of cases of death. Coronavirus can infect all age groups of the population. However, each age group has a different response to this coronavirus. The most vulnerable age groups affected by the spread of COVID-19 and at the highest risk of death are the elderly (Dowd et al. 2020; Leung 2020). The elderly population is an age group that has experienced a decrease in the immune system. It is vulnerable to respiratory tract infections, diarrhea, and pneumonia (Kemenkes RI 2020). This can increase the risk of Coronavirus infection and cause quite severe disorders, even causing death in the elderly population.

The vulnerability of the elderly in terms of health is also reflected in the statistical data of older adults who died due to COVID-19 in many countries. In Malaysia, elderly people who died due to COVID-19 as much as 62.6\% (Astroawani 2020); 85\% in Brazil, 95\% in Italy, 95.5\% in Spain (Escobar, Molina-Cruz and Barillas-Mury 2020); 80\% in China (Detikcom 2020). Meanwhile, in Indonesia, existing information shows that most deaths due to COVID-19 are seniors aged 60 and over (Warta Ekonomi, March 23 2020). Indonesia, which has the fourth-highest population globally, is an important location to map the region's vulnerability to the spread of COVID-19. This mapping aims to provide early information to residents on the status of a region against COVID-19. The region's vulnerability is calculated by comparing the number of older adults with the current population to provide a mathematical picture of the community. Mapping the population's vulnerability on the national scale of East Java Province is the province with the second-highest vulnerability after DKI Jakarta as explained by the Task Force for the Acceleration of Handling COVID-19, which states that East Java is on the COVID-19 vulnerable list due to the high number of older adults, namely $12.64 \%$. From the study results, it is necessary to study in-depth to see the extent of regional vulnerabilities on a local scale. The local scale is referred to in the district and city areas. In an in-depth study, Malang Raya area study, namely Malang City, Batu City, and Malang Regency.

\section{METHOD}

This research aims to describe the vulnerability of the Region to COVID-19 from spatial perspectives. The vulnerability of the region is analyzed based on comparing the number of older adults with the current population. Vulnerability is carried out in more detail studies taking into account gender. This research was conducted in the Greater Malang area, including Malang City, Batu, and Malang Regency. The data was collected using the surveyb123 application from ESRI Indonesia to see the adaptation of people in using personal protective equipment in response to a region's vulnerability. The analysis in this study uses descriptive analysis by comparing the region's vulnerability and the occurrence of COVID-19 in Malang Raya. Vulnerability analysis of COVID-19 is conducted using vulnerability ratio according to the Ministry of Home Affairs of the Republic of Indonesia as follows.

$$
\text { Population Vulnerability Ratio }=\frac{\text { Total population Age above } 60+}{\text { Total population }}
$$


The levels of vulnerability are expressed in the following categories.

- $<0-0.1=$ Low

- $>0.1-0.2=$ Moderate

$->0.2=$ High

(Sumber: Gugus Penangan perception COVID-19)

\section{RESULT AND DISCUSSION}

\subsection{COVID-19 vulnerability mapping in Malang Raya}

The mapping results show that areas are vulnerable to the spread of COVID-19 in the Greater Malang area in rural areas with a ratio of $0.15-0.19$. The high vulnerability in rural areas is due to the high population of $60+$ in the village. This does not close the possibility because of the good quality of the environment and a simple lifestyle. Unlike residents living in urban areas with a lower vulnerability ratio of $0.12-0.14$ than rural communities, COVID-19 is spreading worse In urban area than rural area. Poor environmental quality and modern lifestyle causes city communities to have lower durability despite their awareness of using better personal protective equipment. The following is presented a map of the region's vulnerability level to COVID-19 in the Greater Malang area as seen in figure 1.

Population groups aged $60+$ are one of the indicators or arguably the most vulnerable to COVID-19, as many previous studies have stated that increasing age is also followed by an increasing tendency to get sick and have physical limitations due to a decrease in physical ability that is quite drastic (Gatimu et al. 2016). Meanwhile, according to UGM Geriatric Expert, Probosuseno

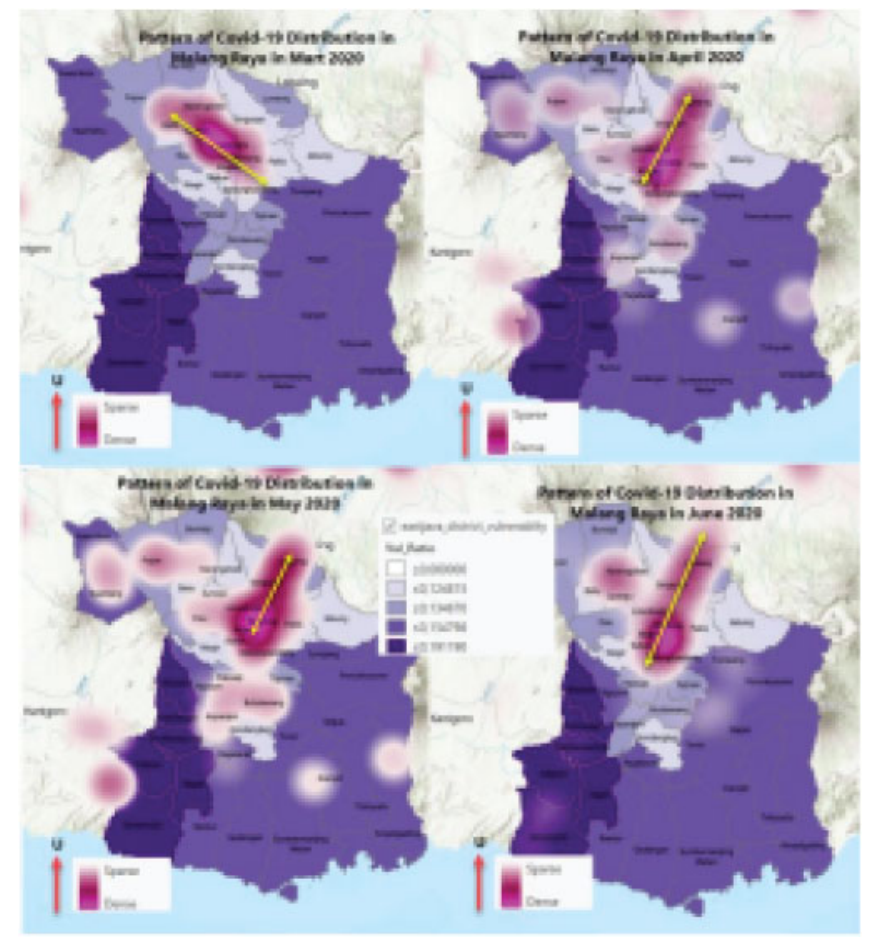

Figure 1. Map of people's vulnerability to COVID-19 in Malang Raya. 
(Berita Harian Update Corona 21 April 2020 Terbaru Hari Ini 2020), the factor that makes the elderly vulnerable to Contracting COVID-19 is because the elderly experience a decrease in functional capacity in almost the entire bodily system, including immunity - coupled with the number of older adults who have congenital diseases such as autoimmune disorders, diabetes, high blood pressure, cancer and heart disease. These facts show that older adults are in a vulnerable position to be infected with COVID-19 (Hakim 2020).

\subsection{Spatial pattern of COVID-19 spread in Malang Raya}

The spread of COVID-19 during the first four months shows a varied dynamic. As pictured above, the beginning of the COVID-19 incident in Malang Raya is concentrated in Malang City's area with the direction of distribution to the Northwest, namely Batu City. The spread shows the strong connection between the two Cities. In April 2020, there was a change of direction northeast towards Surabaya until June 2020. This shows a strong interaction between Surabaya as the provincial capital as well as the second highest city. The second positive case of COVID-19 has a strong impact on the spread of COVID-19 in Malang Raya. The condition is different from other Malang Raya areas, heading to Batu Kediri, Kepanjen and Blitar, and Lumajang. Based on the above conditions, it is believed that accessibility and population density have an important role in preventing the spread of COVID-19. This means that the vulnerability aspect, as the formula above, needs to be supplemented with more complex parameters such as accessibility and population density.

\subsection{Population vulnerability by gender}

Based on the results of an in-depth analysis of 2208 people in Pulungdowo village, Tumpang subdistrict, consisting of 1090 women and 1118 men with an elderly population of 60 years and above as many as 414 people. Of the 414 people of the elderly population, 200 were found by gender, and 200 were male and 214 female. The vulnerability analysis results are presented as shown in Table 1 below.

Table 1. The vulnerability ratio of Pulungdowo villagers to COVID-19.

\begin{tabular}{|c|c|c|c|c|c|}
\hline No & Vulnerability & $\begin{array}{l}\text { Total } \\
\text { Population }\end{array}$ & $\begin{array}{l}\text { Total Elderly } \\
\text { Population }\end{array}$ & $\begin{array}{l}\text { Vulnerability } \\
\text { Ratio }\end{array}$ & Category \\
\hline 1. & Male & 1118 & 200 & 0.1788 & Moderate \\
\hline \multirow[t]{2}{*}{2.} & Female & 1090 & 214 & 0.1963 & Moderate \\
\hline & Average vulnerability & 2208 & 414 & 0.1875 & Moderate \\
\hline
\end{tabular}

The vulnerability analysis results of the population-based on gender showed that the ratio of male vulnerability is lower compared to women. Quantitatively men have a low vulnerability if and the appeal of women is 0.1788 compared to 0.1963 . Still, the facts in the field show the reverse fact, in which men dominate the ratio of positive cases of COVID-19 in Malang Raya. This is because men have a lower awareness of using personal protective equipment than women. The villagers have a moderate level of vulnerability with a very high ratio of 0.1875 . Of these categories, older women had a higher vulnerability ratio than men, with a score of 0.1963 . The results of the analysis are presented in table 1.

Based on the analysis of population vulnerability based on gender type in the elderly, there is a difference in vulnerability between older men and women. Previous research has suggested that men have higher mortality rates, although susceptibility rates are lower than in women. This is because of the content of enzymes in the male blood that the virus uses to infect cells, thus helping the virus survive in the lungs (Science Alert 2020). Referring to the statement, the male elderly population is more vulnerable to COVID-19 exposure than the female elderly population. Exploring the data obtained for villagers' age, the number of older men reached 200 people; the 
number is lower than that of older women of 214 . The results that have been calculated for the vulnerability of men $0.1788 \%$ and women $0.1963 \%$. In general, men are more at risk of COVID- 19 infection because they tend to spend less time on their health care problems than women (Walter and McGregor 2020). Research on the condition of COVID-19 patients in Wuhan, China, resulted in the finding that clinically, men are more susceptible to disease and serious severity than women (Jin et al. 2020).

\section{CONCLUSTIONS}

Based on the results of the study above, it can be concluded that: (1) Rural areas in Malang Raya, based on the results of the analysis, have a high vulnerability ratio due to the high. The high vulnerability is reinforced by low spatial awareness related to the use of personal protective equip ment. But the facts on the ground show the opposite. A simple lifestyle with agricultural work makes villagers more resistant to COVID-19. (2) The spread of COVID-19 in Malang Raya is spatially centralized in Malang, Batu, and along the lines that connect Malang with Surabaya. This is shown by the distribution pattern that extends the road to Surabaya for the last three months. (3) The vulnerability analysis results for the elderly in rural areas based on gender show that women have a higher level of vulnerability than men. However, the awareness of older women using personal protective equipment is high, causing the number of contracting COVID-19 lower.

\section{REFERENCES}

Astroawani, E. (2020) Carian Berita Untuk English Astroawani, 16 april 2020, Astro Awani. Available at: https:/www.astroawani.com/search?q=ingglis+astroawani (Accessed: 24 January 2021).

Berita Harian Update Corona 21 April 2020 Terbaru Hari Ini (2020) Kompas.com. Available at: https://www.kompas.com/tag/update+corona+21+april+2020 (Accessed: 24 January 2021).

Bhattacharya, S., Basu, P. and Poddar, S. (2020) 'Changing epidemiology of SARS-CoV in the context of COVID-19 pandemic', Journal of Preventive Medicine and Hygiene. doi: 10.15167/2421-4248/ jpmh2020.61.2.1541.

Contini, C. et al. (2020) 'The novel zoonotic COVID-19 pandemic: An expected global health concern', Journal of Infection in Developing Countries. doi: 10.3855/jidc. 12671.

Detikcom, T. (2020) Kasus Baru Corona 13 Mei Capai 689 Orang, Kurva Corona MenanjakTinggi, detikNews. Available at: https://news.detik.com/berita/d-5013585/kasus-baru-corona-13- mei-capai-689-orang-kurvacorona-menanjak-tinggi (Accessed: 24 January 2021).

Dowd, J. B. et al. (2020) 'Demographic science aids in understanding the spread and fatality rates of COVID-19', Proceedings of the National Academy of Sciences of the United States of America. doi: 10.1073/pnas.2004911117.

Escobar, L. E., Molina-Cruz, A. and Barillas-Mury, C. (2020) 'BCG vaccine protection from severe coronavirus disease 2019 (COVID-19)', Proceedings of the National Academy of Sciences of the United States of America doi: 10.1073/pnas.2008410117.

Gatimu, S. M., Milimo, B. W. and Sebastian, M. S. (2016) 'Prevalence and determinants of diabetes among older adults in Ghana', BMC Public Health. doi: 10.1186/s12889-016-3845-8.

Hakim, L. N. (2020) 'Pelindungan Lanjut Usia Pada Masa Pandemi COVID-19', Perlindungan lanjut usia pada masa pandemi COVID-19.

Jin, J. M. et al. (2020) 'Gender Differences in Patients With COVID-19: Focus on Severity and Mortality', Frontiers in Public Health. doi: 10.3389/fpubh.2020.00152.

Kemenkes RI (2020) Penelusuran Google. Available at: https://www.google.com/search?q=Kemenkes+RI\% $2 \mathrm{C}+2020 \&$ oq $=$ Kemenkes $+\mathrm{RI} \% 2 \mathrm{C}+2020 \&$ aqs $=$ chrome..69i57j015j0i22i3014.943j1j7\&sourceid $=$ chrome \& ie $=$ UTF-8 (Accessed: 24 January 2021).

Lau, H. et al. (2020) 'The positive impact of lockdown in Wuhan on containing the COVID-19 outbreak in China', Journal of travel medicine. doi: 10.1093/jtm/taaa037.

Leung, C. (2020) 'Risk factors for predicting mortality in elderly patients with COVID-19: A review of clinical data in China', Mechanisms of Ageing and Development. doi: 10.1016/j.mad.2020.111255. 
Majumdar, P., Biswas, A. and Sahu, S. (2020) 'COVID-19 pandemic and lockdown: cause of sleep disruption, depression, somatic pain, and increased screen exposure of office workers and students of India', Chronobiology International. doi: 10.1080/07420528.2020.1786107.

Otálora, M. M. C. (2020) 'YULIANA', in Parque de los afectos. Jóvenes que cuentan. doi: 10.2307/j. ctvzxxb18.12.

Shammi, M. et al. (2020) 'Strategic assessment of COVID-19 pandemic in Bangladesh: comparative lockdown scenario analysis, public perception, and management for sustainability', Environment, Development and Sustainability. doi: 10.1007/s10668-020-00867-y.

Shereen, M. A. et al. (2020) 'COVID-19 infection: Origin, transmission, and characteristics of human coronaviruses', Journal of Advanced Research. doi: 10.1016/j.jare.2020.03.005.

Thornton, J. (2020) 'COVID-19: A\&E visits in England fall by 25\% in week after lockdown', BMJ (Clinical research ed.). doi: 10.1136/bmj.m1401.

Walter, L. A. and McGregor, A. J. (2020) 'Sex- And gender-specific observations and implications for COVID-19', Western Journal of Emergency Medicine. doi: 10.5811/westjem.2020.4.47536.

WHO (2020) 'Coronavirus disease (COVID-2019) situation reports', World Health Organisation. 